\title{
Invertebrate-Interactive Dichotomous Key Media: Enhance Students Learning Motivation in Lower Secondary School
}

\author{
Rizhal Hendi Ristanto, Mieke Miarsyah, Ilena Amalia Luthfi, Endah Kristiani, and Risky Hasanah
}

\begin{abstract}
The purpose of this research is to develop interactive learning media about classification of organisms. This research used modification of 4D method (Define, Design, Develop, and Disseminate from Thiagarajan et al., 1974). Invertebrate Interactive Dichotomous Key (Invertebrate-IDKM) is given in the learning at lower secondary school. Percentage of the expert validation is $80 \%$. According to the validation result, we conclude that Invertebrate-IDKM is valid in the media, materials, languages, and eligible in the learning about the classification of organisms especially classification of invertebrate animals. Invertebrate-IDKM increases learning motivation especially lower secondary school students because it encourages interaction and use technology.
\end{abstract}

Index Terms-4D method, interactive media, Invertebrate-IDKM, motivation.

\section{INTRODUCTION}

Creative learning is a pillar of $21^{\text {st }}$ century learning. It has been change teacher centered learning into contextual student centered [1]. Teachers only act as facilitators who support the learners to have the 4C's ability (Critical Thinking, Communication, Collaboration, and Creativity) [2]. Learning in $21^{\text {st }}$ century encourages educators to have roles and responsibilities in preparing their students to have $4 \mathrm{C}$ abilities [3], [4]. The use of technology-based learning media is one of the characteristics of $21^{\text {st }}$ century learning that is synonymous with artificial intelligence, automation and digitalization [5].

Biology learning leads students to have more opportunities to master the 4C's ability. Various topics in biology build creative thinking skills and problem-solving abilities for students [6]. The ability to think for students makes it easy to recognize objects in the environment. Students' thinking skills can be improved through various media, models, and other learning tools prepared by the teacher [7], [8].

Learning biology that is abstract requires visualization in the form of images or videos. The audio-visual media is needed for students understanding [9]. Multimedia can be learning tools that can serve as a substitute teacher for several activities such as giving instructions and demonstration [10].

One of the topic's in biology is classification of living things (taxonomy). Taxonomy originates from the similarity of the characteristics of living things to find relationship

Manuscript received February 8, 2020; revised April 6, 2020.

The authors are with the Department of Biology Education, Universitas Negeri Jakarta, Indonesia (e-mail: rizhalhendi@unj.ac.id, mmiarsyah@unj.ac.id,_ilenaamalia12@gmail.com, endahkristiani2004.ek@gmail.com, riskyhasanah27@gmail.com). between living things [11]. The characteristics of living things are arranged in a dichotomous manner, displaying the classification of living things known as the dichotomous key. The dichotomous key is a tool that allows users to determine the identity of living things. The key consists of two choices of characteristics that direct the user to the name or the group of organisms. The dichotomous key is difficult to apply to students. This is due to the interest in using the dichotomous key is not the same for each student. The role of interactive media has a purpose in increasing students' interest and motivation [12], [13].

The development of multimedia online making the identification living things easy [11]. Ref. [11] used three types of media interface in their there are Field guide, Feature selection and Decision Tree. The results showed that the digital interface improve decision making and independent learning processes when students carry out complex species identification tasks. This research concluded that the identification of living things using digital equipment improves the learning process of students.

M-learning Vertebrate determination program is one of the software in digital mobile devices [14]. The software is a technology-based multimedia developed to improve the reasoning ability. Mobile learning makes the learning process becomes more interactive. It also carries the transformation from traditional to modern learning. M-learning Vertebrate Determination program significantly increases the reasoning and classification ability that can be seen from the increasing results of the students' pretest and posttest after using the media. Students feel that the media has interesting visuals, provides many benefits, easy to use, and makes easy to understand vertebrate classification.

Classification skill is needed in using dichotomous keys [14]. Classification's skill involves the process of organizing objects into groups based on observed characteristics. Dichotomous key is the multidimensional disciplines that describe characteristics, naming, and determining relationships between species [15]. Technology integrated in learning increase student's interest, which will be followed by the increasing of motivation so that learning outcomes improve.

Through the various studies above, it can be seen that the online dichotomous key learning media have been developed. There is still a need for an interactive dichotomous key media that is offline so that it can be used more widely, especially for schools with limited internet facilities. The learning media developed are expected to play a role in increasing learning motivation which impacts on students' understanding of the classification of living things. The 
developed media can be accessed using digital device in accordance with the needs and interests of students. This interactive media is expected to help students in the process of living things' classification and to understand the dichotomous key.

\section{METHOD}

This research was conducted in November 2019 - January 2020. This type of research is the $R$ \& D using the modification of 4D model [16]. This model consists of four phases: Define, Design, Develop, and Disseminate. This research was limited during the develop phase because it is still an early stage for further research.

Define phase is done by analyzing the needs of media development. Requirement analysis is carried out by analyzing the Basic Competencies of class VII on the material classification of living things to determine the competencies that need to be achieved by students through the media to be developed. In addition, an analysis of students' learning motivation is done through a questionnaire that can provide information about the needs of students towards the media in learning biology.

The second phase is design by compiling material about the classification of living things in the sub-chapter classification of invertebrates, creating a learning media framework, compiling an instrument of media validity, compiling a learning motivation questionnaire and an instrument of students' responses to the use of the media. Preparation of invertebrate classification material was developed by making a dichotomous key from eight invertebrate phyla. Specifying images, animations, and audio in detail with storyboarding makes it easy to make media so that the media is easy to use and help students to learn. The instrument of media validity is in the form of a questionnaire aimed at media experts, material experts, and biology teachers based on educational background, expertise in accordance with qualifications, experience in using biology learning media, and biology teachers who are certified as educators. Improvement of student learning motivation is measured using a questionnaire with a Likert scale given before and after learning.

The last phase is the develop, carried out by making interactive media regarding to the storyboard named Invertebrate-Interactive Dichotomous Key Media (Invertebrate-IDKM). This media contains dichotomous key, especially invertebrate animals. After developed, the validity test is done to determine the feasibility of a media. Validity test is carried out on media experts, material experts, and biology teachers. Score data obtained were averaged for each aspect and converted into a percentage using the following formula [17]. The validity test also serves to receive criticism and suggestions for improving Invertebrate-IDKM. After the media was repaired based on suggestions, the next step was to test the use of Invertebrate-IDKM on 33 bilingual VII grade students of SMPK 4 Penabur Jakarta who had previously been given a learning motivation questionnaire at the need analysis stage. Learning motivation and responses to the media questionnaire were given after students used Invertebrate-IDKM.
TABLE I: CATEGORY OF VALIDATION

\begin{tabular}{ccc}
\hline \hline Score Scale (100\%) & Validity Criteria & Description \\
\hline $81-100$ & Strongly valid & Not Revise \\
\hline $61-80$ & Valid & Not Revise \\
\hline $41-60$ & Fairly valid & Revise \\
\hline $21-40$ & Less valid & Revise \\
\hline $0-20$ & Strongly not valid & Revise \\
\hline \hline
\end{tabular}

\section{DISCUSSION}

\section{A. Development of Invertebrate-IDKM}

Invertebrate Interactive Dichotomous Key Media (Invertebrate-IDKM) was developed in English and contains five main menus, there are Rules, Phylum, Question, and Glossaries. This media consists of images, animations, descriptions, audio explanations, and involves responses from users so that Invertebrate-IDKM is included as interactive media.

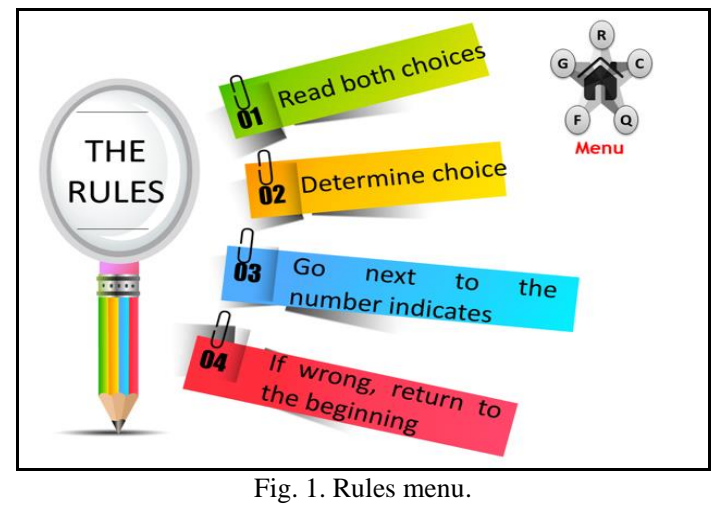

Fig. 1 displays the Rules menu that contain the instructions for using dichotomous Invertebrate-IDKM. With the rules of the use of media, students will more easily use the media in learning.

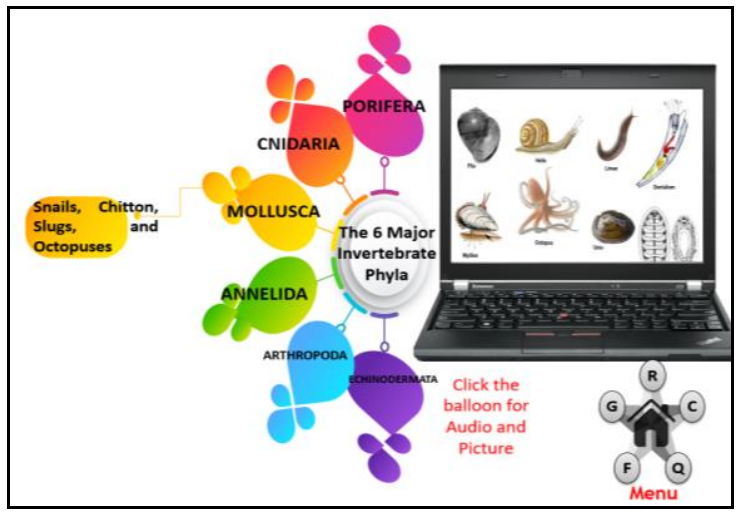

Fig. 2. Phylum menu

Collection of material in the form of animals and sample audio explanation about each of the phyla were on the Phylum menu (Fig. 2). Through this menu learners are expected to understand the characteristics of each phylum.

Fig. 3 displays the Question menu's, students are trained to use the dichotomous key to get the phylum of each organism displayed. In this menu, there are two choices of answers that match with the characteristics observed before proceeding to the next choices. There is a response from the media in each 
answer that students choose, so there is interaction between the media and users.

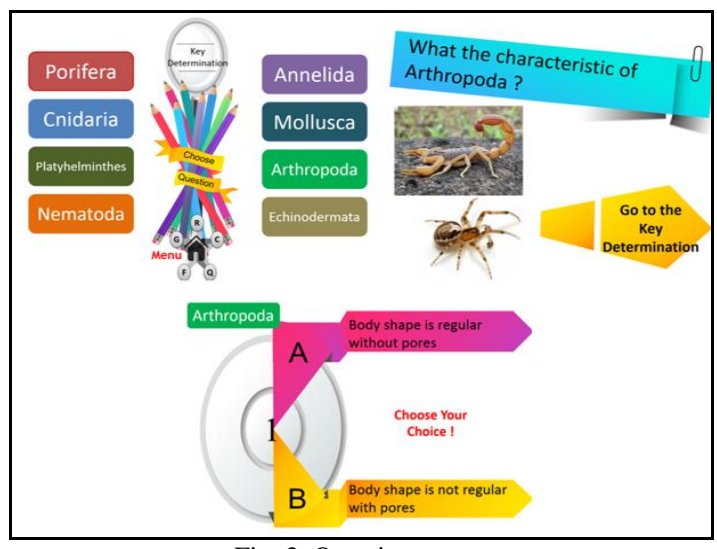

Fig. 3. Question menu.

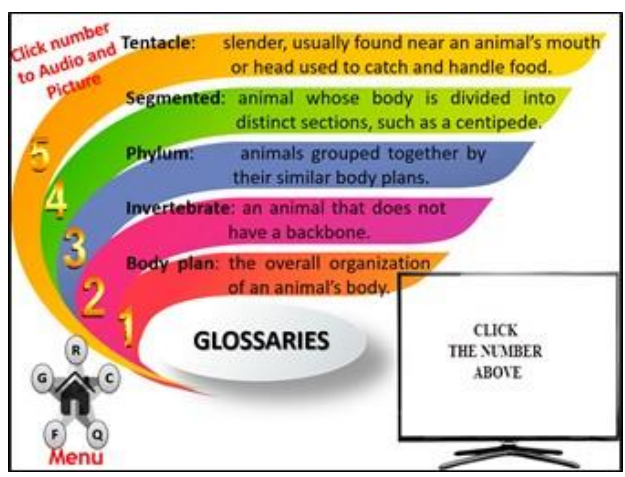

Fig. 4. Glossaries menu.

Glossaries menu in Fig. 4 contains important terms and the explanations about classification of living things. Students also get an explanation with audio about these important terms.

After developing the media, the next step is to test the validity of the media to the experts. Table II represents the validation results:

TABLE II: VALIDATION RESULT

\begin{tabular}{c|lcc}
\hline \hline Num & \multicolumn{1}{|c}{ Indicator } & Percentage & Category \\
\hline 1. & Display and color & $80 \%$ & Valid \\
2. & Size of font & $82 \%$ & Strongly \\
Valid \\
3. & Effectiveness & $78 \%$ & Valid \\
4. & Language & $80 \%$ & Valid \\
5. & Relevance of material & $80 \%$ & Valid \\
6. & Compatibility of material & $81 \%$ & Strongly \\
& with the Basic Competence & & Valid \\
\hline & Average & & Valid \\
\hline
\end{tabular}

The results of the validation based on the table show that in general Intervertebrate-IDKM is suitable to be used as a learning media for the classification of living things. Based on the assessment of the experts, an average score of $80 \%$ is declared valid.

Invertebrate-IDKM has the advantage of being used offline and interactive. The use of media that is offline can make it easier for students as a tool in understanding learning because it does not require internet networks which often become obstacles in the use of technology-based media. These barriers usually occur in schools with inadequate facilities. Interactive media contains images, animation, and audio as well as the interaction between the media and the user. This can lead to motivation or interest of students in the learning process.

Classification of living things contains a lot of memorization about the characteristics of living things and scientific terms, because of that students find it difficult to understand [14]. Invertebrate-IDKM is an innovation in learning media in the $21^{\text {st }}$ century that has the characteristics of being technology-based and interactive. With technology-based and interactive media, learning will be more interesting and increase student understanding [11]-[18].

Interactive media has many advantages in the learning process, one of the advantages is to helps the learning process become active [19]. In the $21^{\text {st }}$ century learning, students are expected to learn independently. The use of media in the learning process helps to reach that expectation [20]. But the role of the teacher is still important to get the student-centered learning. Teachers can continue to generate motivation to create a conducive learning atmosphere. Using Invertebrate-IDKM in learning make learning more active [21], [22].

\section{B. Learning Motivation of Students}

Student learning motivation is measured to find out the motivation before and after learning using InvertebrateIDKM. Based on the needs analysis at the Define stage, $85 \%$ of students need interesting learning media to help understand the topic of classification of living things. The motivation questionnaire consisted of 26 statements compiled based on relevant indicators looking at the intrinsic and extrinsic factors of students' learning motivation. Learning motivation arise due to intrinsic factors in the form of a desire or desire to succeed and the drive for learning needs to achieve goals, while the extrinsic factor arise due to appreciation, a conducive learning environment, and interesting learning activities [23].

TABLE III: THE PERCENTAGE OF STUdENT MOTIVATION

\begin{tabular}{cccc}
\hline \hline Time & $\begin{array}{c}\Sigma \text { Maximum } \\
\text { score }\end{array}$ & $\begin{array}{c}\Sigma \text { Student } \\
\text { score }\end{array}$ & Percentage \\
\hline Before learning & \multirow{2}{*}{4.290} & 2.847 & $67 \%$ \\
After learning & & 3.124 & $73 \%$ \\
\hline \hline
\end{tabular}

The results showed that the percentage of learning motivation increase from $67 \%$ before learning to $73 \%$ after learning using Invertebrate-IDKM. The use of interactive and technology-based media in learning increases student motivation which will have an impact on the effectiveness of the learning process [13]-[24].

To improve the quality of education, it is necessary to develop learning innovations [25], [26]. In the learning process, teachers are expected to create learning conditions that can motivate students to learn by using interesting media so that learning objectives are achieved. The increase in learning motivation shows that Invertebrate-IDKM is effective to increase students' learning motivation, especially in the topic of classification of living things.

\section{Student Responses to Invertebrate-IDKM}

The results of the responses questionnaire of students after using Invertebrate-IDKM showed positive responses. Students give the response based on display and color, 
language, and the effectiveness of the media. Table IV represents that $93 \%$ students stated that Invertebrate-IDKM is an interesting medium in terms of the images, animation and audio aspects presented. In language indicators, $88 \%$ of students stated that the language was communicative and easy to understand in understanding learning material, and $85 \%$ students stated that Invertebrate-IDKM is an easy medium to use in learning Students give positive responses to Invertebrate-IDKM because the media has attractive and interactive display. Invertebrate-IDKM as the digital-based media can be used offline so that it does not require internet network.

\begin{tabular}{lc} 
TABLE IV: STUDENT RESPONSES TO INVERTEBRATE-IDKM \\
\hline \multicolumn{1}{c}{ Indicator } & Percentage \\
\hline Display and color & $93 \%$ \\
Language & $88 \%$ \\
Effectiveness of media & $85 \%$ \\
\hline \hline
\end{tabular}

\section{CONCLUSION}

The interactive learning media Invertebrate-IDKM, is suitable for use in lower secondary school students learning based on the media, material, and language. This media also increasing student learning motivation, especially for studying the classification of living things. But this media still needs to be applied more broadly so that it can be felt by other students.

\section{CONFLICT OF INTEREST}

The authors declare that there is no conflict of interest regarding the publication of this paper.

\section{AUTHOR CONTRIBUTIONS}

All authors conducted the research and wrote the research paper.

\section{REFERENCES}

[1] A. Juhanda and Y. Maryanto, "The emergence of biological problems in electronic school books (BSE) class $\mathrm{x}$ reviewed from the scientific knowledge domain of scientific literacy," Biosfer: Jurnal Pendidikan Biologi, vol. 11, no. 2, pp. 121-125, 2018.

[2] C. Kivunja, "Exploring the pedagogical meaning and implications of the 4cs "super skills" for the 21 st century through bruner's $5 \mathrm{e}$ lenses of knowledge construction to improve pedagogies of the new learning paradigm," Creative Education, vol. 6, no. 2, pp. 224-239, 2015.

[3] Ş. S. Anagun, "Teachers' perceptions about the relationship between 21st century skills and managing constructivist learning environments," International Journal of Instruction, vol. 11, no. 4, pp 825-840, 2018.

[4] A. Chalkiadaki, "A systematic literature review of 21st century skills and competencies in primary education," International Journal of Instruction, vol. 11, no. 3, pp. 1-16, 2018.

[5] R. Djamahar, R. H. Ristanto, N. Sartono, I. Z. Ichsan, and A. Muhlisin, "Cirsa: designing instructional kits to empower 21st century skill," Educational Process: International Journal, vol. 7, no. 3, pp. 200-208, 2018.

[6] C. Murphy, L. Bianchi, J. McCullagh, and K. Kerr, "Scaling up higher order thinking skills and personal capabilities in primary science: Theory-into-policy-into-practice," Thinking Skills and Creativity, vol. 10 , pp. 173-188, 2013.

[7] C. C. Chang, C. Liang, P. N. Chou, and G. Y. Lin, "Is game-based learning better in flow experience and various types of cognitive load than non-game-based learning? Perspective from multimedia and media richness," Computers in Human Behavior, vol. 71, pp. 218-227, 2017.
[8] T. F. Wall, "The transferability of higher order cognitive skills," Procedia - Social and Behavioral Sciences, vol. 174, pp. 233-238, 2015.

[9] A. Musyaddad and S. Suyanto, "Evoking the four dimensions of student knowledge in ecosystem: Effectiveness of real object, web, and blended learning," Biosfer: Jurnal Pendidikan Biologi, vol. 12, no. 2, pp. 194-210, 2019

[10] B. F. Ngonso, P. E. Egielewa, and A. E. Nyong, "Influence of interactive media on communication education in Nigeria: A study of the use of power point in teaching mass communication," Global Media Journal, vol. 16, no. 31, pp. 1-7, 2018.

[11] N. Sharma, L. C. Gray, A. Siddharthan, R. Comont, and R. V. D. Wal, "Designing online species identification tools for biological recording: The impact on data quality and citizen science learning," Peer J., vol. 6, 2019.

[12] W. D. Riyant and G. Gunarhadi, "The effectiveness of interactive multimedia in mathematic learning (utilizing power points for students with learning disability)," International Journal of Pedagogy and Teacher Education (IJPTE), vol. 1, no. 1, pp. 55-63, 2017.

[13] L. M. Jeno, J. A. Grytnes, and V. Vandvik, "The effect of a mobile-application tool on biology students' motivation and achievement in species identification: A Self-Determination Theory perspective," Computers \& Education, vol. 107, no. 1, pp. 1-12, 2017.

[14] R. N. Subekti, R. Riandi, and B. Supriatno, "Development of m-learning vertebrate determination program to improve student's classification and reasoning skills," Journal of Physics: Conference Series, pp. 1-6, 2019.

[15] S. Schaal, M. Matt, and S. Grubmeyer, "Mobile learning and biodiversity - bridging the gap between outdoor and inquiry learning in pre-service science teacher education," Journal of Social and Behaviour Science, vol. 46. pp. 2327-2333, 2012.

[16] S. Thiagarajan, D. S. Semmel, and M. I. Semmel, Instructional Development for Training Teachers of Exceptional Children: A Sourcebook. Minneapolis: Leadership Training Institute/Special Education, University of Minnesota, 1974.

[17] S. Rosamsi, M. Miarsyah, and R. H. Ristanto, "Interactive multimedia effectiveness in improving cell concept mastery," Journal of Biology Education, vol. 8, no. 1, pp. 56-61, 2019.

[18] H. F. Bachrum, S. Purwantoro, and L. Lestari, "Rancang bangun aplikasi pembelajaran 3d klasifikasi makhluk hidup kingdom monera dan protista berbasis desktop untuk peserta didik sekolah menengah pertama (SMP)," Jurnal Komputer Terapan, vol. 5, no. 1, pp. 36-44, 2019.

[19] M. Qian and K. R. Clark, "Game-based learning and 21st century skills: A review of recent research," Computers in Human Behavior, vol. 63, pp. 50-58, 2016

[20] R. H. Ristanto, M. Miarsyah, D. R. Muharomah, T. A. Astuti, S. Aini, and A. I. Prihatin, "Light-board: Simple media to learn photosynthesis concepts," International Journal of Advanced Trends in Computer Science and Engineering, vol. 9, no. 1, pp. 299-303, 2019.

[21] H. Norman, N. Nordin, R. Din, and M. Ally, "Modeling learner situation awareness in collaborative mobile web 2.0 learning," Journal of Education and Technology, vol. 4, no. 1, pp. 32-56, 2016.

[22] P. Lestari, R. Ristanto, and M. Miarsyah, "Analysis of conceptua understanding of botany and metacognitive skill in pre-service biology teacher in Jakarta, Indonesia," Journal for the Education of Gifted Young Scientists, vol. 7, no. 2, pp. 199-214.

[23] H. B. Uno, Teori Motivasi dan Pengukurannya: Analisis di Bidang Pendidikan, Jakarta: Bumi Aksara, 2006, p. 23.

[24] L. R. Ningsih, R. Rusdi, and M. Miarsyah, "Exploring respiratory system to improve biological learning motivation: Resysmart media application," Biosfer: Jurnal Pendidikan Biologi, vol. 12, no. 2, pp 211-223, 2019.

[25] M. Miarsyah, R. H. Ristanto, Nurhayati, S. N. Mufida, Suparini, and A E. Zharroh, "Development of adobe flash media integrated into hots on circulation system (Af-hots bicycle media)," International Journal of Advanced Trends in Computer Science and Engineering, vol. 9, no. 1, pp. 896-903, 2020.

[26] Supriyatin, S. Rahayu, R. H. Ristanto, and I. Z. Ichsan, "Improving hots in biology learning: A supplement book of plant growth and development," Universal Journal of Educational Research, vol. 7, no. 12, pp. 2642-2646, 2019.

Copyright $\odot 2020$ by the authors. This is an open access article distributed under the Creative Commons Attribution License which permits unrestricted use, distribution, and reproduction in any medium, provided the original work is properly cited (CC BY 4.0). 


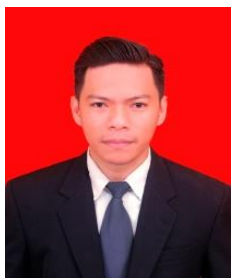

Rizhal Hendi Ristanto received his doctor of biology education from Universitas Negeri Malang, Indonesia in 2017. Some of his publication research are "Ethnoveterinary Pharmacology: Knowledge Identification of Sukarame Society, Carita, Pandeglang, Banten"; "Analysis of Conceptual Understanding of Botany and Metacognitive Skill in Pre-Service Biology Teacher in Jakarta, Indonesia"; and "From a reader to a scientist: developing cirgi learning to empower scientific literacy and mastery of biology concept".

Dr. Rizhal is a lecturer at biology education, Universitas Negeri Jakarta, Indonesia. He is currently lecturer in Department of Biology Education, Universitas Negeri Jakarta, Indonesia.

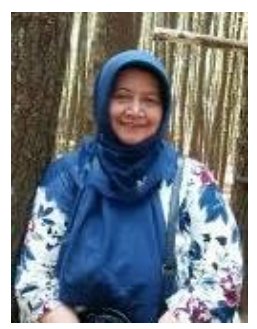

Mieke Miarsyah received her doctor of environmental education from Universitas Negeri Jakarta, Indonesia in 2015. Some of her publication research are "Effectiveness lekers mulia (student worksheet based on multimedia) and the level of knowledge on the attitude of environmental responsibility"; "MEBA: Development Android-based Ecosystem Module for Senior high school students"; and "Interactive Multimedia Effectiveness in Improving Cell Concept Mastery". Dr. Mieke is a lecturer at biology education, Universitas Negeri Jakarta, Indonesia. She is currently an associate professor at Faculty of Mathematics and Natural Science, Universitas Negeri Jakarta, Indonesia.

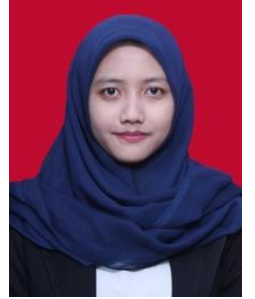

Ilena Amalia Luthfi received her bachelor degree in Department of Biology Education from Universitas Islam Negeri Syarif Hidayatullah Jakarta, Indonesia in 2018. She is a graduate student in biology education, Faculty of Mathematics and Natural Science, Universitas Negeri Jakarta, Indonesia. Her publication research is "Students Attitude to Conserve Medicinal Plants and Environment in Cipanas: Profile and Comparative Analysis".

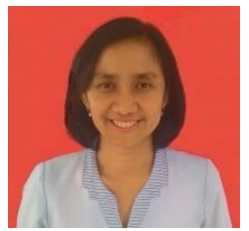

Endah Kristiani received her bachelor degree in Department of Biology Bandung Institute of Technology, Indonesia in 1999. She is a graduate student in biology education, Faculty of Mathematics and Natural Science, Universitas Negeri Jakarta, Indonesia; and alower secondary school teacher at BPK Penabur Jakarta, Indonesia.

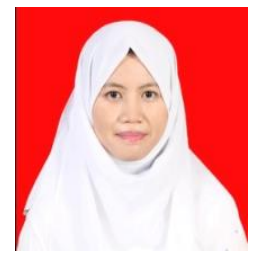

Risky Hasanah received her bachelor degree in Department of Biology Education, Universitas Negeri Jakarta, Indonesia in 2017. She is a graduate student in biology education, Faculty of Mathematics and Natural Science, Universitas Negeri Jakarta, Indonesia. Her publication research is "Higher Order Thinking Skills Assessment based on Environmental Proble, (HOTS-AEP)" 